\title{
Hypoglycemic and Hypolipidemic Effects of Raisin Aqueous Extract “Karkni” in Alloxan-Induced Diabetic Rats
}

Fatma Ghrairi ${ }^{1}$, El Arem Amira ${ }^{2}$, Chahed Henda ${ }^{3}$, Lamia Lahouar ${ }^{2}$, Lotfi Achour ${ }^{2}$ and Salem Said ${ }^{1}$

${ }^{1}$ Laboratory of Biochemistry, Mohamed Karoui Avenue, Tunisia

${ }^{2}$ Higher Institutes of Biotechnology, Tahar Hadded Avenue, Tunisia

${ }^{3}$ Laboratoiry of Biochemistry, Hospital Farhat Hachad Sousse, Sousse, Tunisia

\begin{abstract}
The present study was carried out to investigate the possible antioxidant effects of raisin extract "Karkni" on biochemical parameters in alloxan-induced diabetic rats. Three doses of extract, 125,250 and $375 \mathrm{mg} / \mathrm{kg}$ were orally administered daily to alloxan-diabetic rats for 4 weeks. Alloxan-induced diabetic rats showed significant increases in the levels of blood glucose, triglycerides, cholesterol, low density lipoprotein LDL-cholesterol, creatinine, uric acid , total protein, glycosylated hemoglobin ( $\mathrm{HbA1c}$ ), Aspartate aminotransferase (AST) and alanine aminotransferase (ALT) while high density lipoprotein HDL cholesterol, total hemoglobin and lactate dehydrogenase (LDH) levels were significantly decreased compared to normal rats $(P<0.05)$. The changes of the above parameters to their normal levels after 4 weeks of treatment were observed mainly with the second dose $250 \mathrm{mg} / \mathrm{kg}$. The overall results suggest that the "Karkni" extract possesses potential hypoglycemic and hypolipidemic activity in alloxan-induced diabetic rats.
\end{abstract}

Keywords: Karkni; Rats; Alloxan; Hypoglycemic; Hypolipidemic; Biochemical parameters

\section{Karkni; Rats; Alloxan; Hypoglycemic; Hypolipidemic; Biochemical parameters}

Diabetes is a major degenerative disease in the world today [1], affecting at least 15 million people and having complications which include hypertension, atherosclerosis and microcirculatory disorders [2]. It is also associated with long-term complications, including retinopathy, nephropathy, neuropathy and angiopathy [3-5]. Controlling blood sugar levels and keeping these closer to normal values is able to reduce the risk of diabetes and death by these complications. Since dietary carbohydrates had the most direct impact on blood sugar levels, controlling the amount of carbohydrate consumed per meal is the focus of diabetes nutrition management [6]. Raisins, like all commonly consumed fruits, provide carbohydrates as the only caloric macronutrient but it is considered as a great source of many polyphenolic compounds (flavonoids, tannins, phenolic acid) playing important roles in nutrition and health care $[7,8]$. Spiller et al. [9] first studied the hypocholesterolemic effect of plant-based diets, which included more than one serving of sun-dried raisins daily. Keen and schram showed that a diet providing 2, 3.5 and 5.5 ounces of raisins per day for 4 weeks lowered ox-LDL levels [10]. Besides, research suggest that addition of raisins to the daily diet has been shown to lower total and LDL cholesterol levels, reduce markers of inflammation, increase plasma antioxidant capacity and lower circulating levels of oxidized LDL, a marker of coronary heart disease risk $[11,12]$. Also browning reaction products (BRPs) in raisin have been reported to prevent or retard oxidation reactions in lipid systems $[13,14]$, because they have similar chemical properties as phenolic acids [15]. Experimental diabetes in animals has the advantage that it allows the analysis of the biochemical events that take place not only during the induction of a diabetic state but also after it has become established and during its evolution to a severe insulin deficiency or even death [16]. Alloxan is a specific toxin that destroys the pancreatic $\beta$ cells, provoking a state of primary deficiency of insulin without affecting other islet types $[17,18]$. Hence, it was selected to induce diabetes in the present study and the principal objective was to determine the potential beneficial antidiabetic effects of three concentrations of raisin extract $(125,250$ and $375 \mathrm{mg} / \mathrm{kg}$ ) during 4 weeks on alloxan-induced diabetic rats.

\section{Materials and Methods}

\section{Plant material}

Dried fruit was extracted with distilled water by grinding with a mortar and pestle. It was incubated for $24 \mathrm{~h}$ and filtered using a Buckner funnel and Whatman No. 1 filter paper. It was the filtrate that was administered to the animals in the course of this study, fresh for a maximum of two days after which fresh extract was prepared.

\section{Experimental animals}

Male Wistar rats (Société des Industries Pharmaceutiques Tunis, Tunisia), weighing 200-250 g were housed under standard environmental conditions $\left(23^{\circ} \mathrm{C}, 55 \pm 5 \%\right.$ humidity and a $12 \mathrm{~h} \mathrm{light} / \mathrm{dark}$ cycle) and maintained with free access to water and a standard diet ad libitum. Experimental diabetes was induced in rats by intraperitoneal injection of alloxan monohydrate at a dose of $120 \mathrm{mg} / \mathrm{kg}$. After 2 weeks, animals with blood glucose levels of $200 \mathrm{mg} / \mathrm{dl}$ and above were considered diabetic. The rats were divided into 5 groups of 8 animals per group. Group 1: Non-diabetic untreated rats (Control), Group 2: Diabetic untreated rats, Group 3: Diabetic rats treated with $125 \mathrm{mg} / \mathrm{kg}$ "Karkni" extract (D+C1), Group 4: Diabetic rats treated with $250 \mathrm{mg} /$ $\mathrm{kg}$ of the "Karkni" extract $(\mathrm{D}+\mathrm{C} 2)$ and Group 5: Diabetic rats treated

*Corresponding author: Fatma Ghrairi, Laboratory of Biochemistry, Faculty of Medicine Sousse, Mohamed Karoui Avenue, 99/UR/08-45, 4002 Sousse, Tunisia Fax: +216 73224899; E-mail: fatma_ghrairi@yahoo.fr

Received July 27, 2012; Accepted September 14, 2012; Published Septembe 19, 2012

Citation: Ghrairi F, Amira EA, Henda C, Lahouar L, Achour L, et al. (2012) Hypoglycemic and Hypolipidemic Effects of Raisin Aqueous Extract "Karkni" in Alloxan-Induced Diabetic Rats. J Diabetes Metab 3: 211. doi:10.4172/2155 6156.1000211

Copyright: @ 2012 Ghrairi F, et al. This is an open-access article distributed unde the terms of the Creative Commons Attribution License, which permits unrestricted use, distribution, and reproduction in any medium, provided the original author and source are credited. 
Citation: Ghrairi F, Amira EA, Henda C, Lahouar L, Achour L, et al. (2012) Hypoglycemic and Hypolipidemic Effects of Raisin Aqueous Extract "Karkni" in Alloxan-Induced Diabetic Rats. J Diabetes Metab 3: 211. doi:10.4172/2155-6156.1000211

with $375 \mathrm{mg} / \mathrm{kg}$ of the "Karkni" extract (D+C3). After confirming diabetes, "Karkni" extract was administered orally, in the morning, once every 24 hours for 4 weeks. At the end of this treatment period, the animals were fasted overnight for 12 hours. Blood samples from rats were collected under mild ether anesthesia in heparinized tubes and centrifiguted at $3000 \mathrm{~g}$ for $15 \mathrm{~min}$ at $4^{\circ} \mathrm{C}$. Plasma samples were stored at $-20^{\circ} \mathrm{C}$ in aliquots until analysis. All experimental protocols used were in accordance with the guidelines of the local Committee on Use of Laboratory Animals.

\section{Experimental procedure}

TC and HDL cholesterol, Creatinine, Urea, Uric acid, Total protein in plasma were determined by colorimetric method, whereas LDL cholesterol was calculated by the method of Friedewald et al. [19]. Coronary Risk Index (CRI) was calculated by dividing the Total Cholesterol (TC) by High density lipoprotein (HDL). Glycosylated haemoglobin (HbAlc) was estimated using whole blood. Hemoglobin, LDH, $\gamma$-GT, Alanine Aminotransferase, and Aspartate Aminotransferase activity levels in the plasma were estimated by using standard kits purchased from Biomaghreb [20-23].

\section{Statistical analysis}

Data were subjected to one-way analysis of variance for means of comparison, and significant differences were calculated according to Duncan multiple range test. Data are reported as means \pm standard error of the means. Differences at $\mathrm{P}<0.05$ were considered statistically significant. SPSS (version 11.0) was used to perform the statistical analysis.

\section{Results}

\section{Effects of "Karkni" extract on blood glucose levels}

The effects of "Karkni" extract on blood glucose levels in diabetic rats were shown in figure 1 . The blood glucose levels of rats in the control group did not change during the experimental period. By contrast the blood glucose levels in diabetic group were significantly higher $(\mathrm{P}<0.05)$ than those of the treated rats in the other groups;

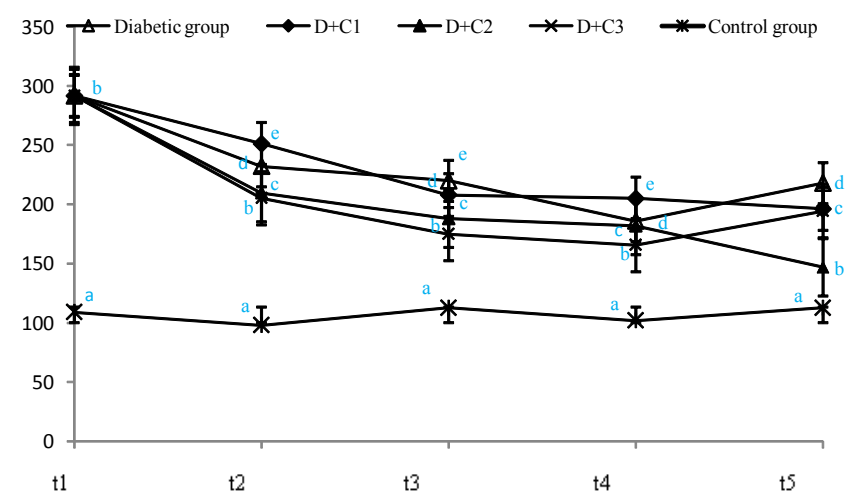

Figure 1: Effect of "Karkni" extract treatment on blood glucose levels in diabetic rats. Values with different superscript letters $(a, b, c)$ indicate significant differences among groups at $\mathrm{P}<0.05$ by Duncan's multiple range test.

C: Control; D: Rats with Alloxane-induced diabetes; D+C1: rats treated with 125 $\mathrm{mg} / \mathrm{kg} /$ day; $\mathrm{D}+\mathrm{C} 2$ : rats treated with $250 \mathrm{mg} / \mathrm{kg} /$ day; $\mathrm{D}+\mathrm{C} 3$ : rats treated with 375 $\mathrm{mg} / \mathrm{kg} / \mathrm{day}$

\section{ALAT activity $U / L$}

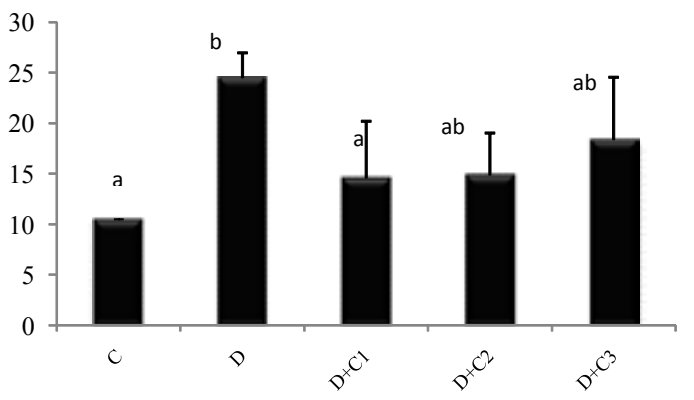

ASAT Activity U/L

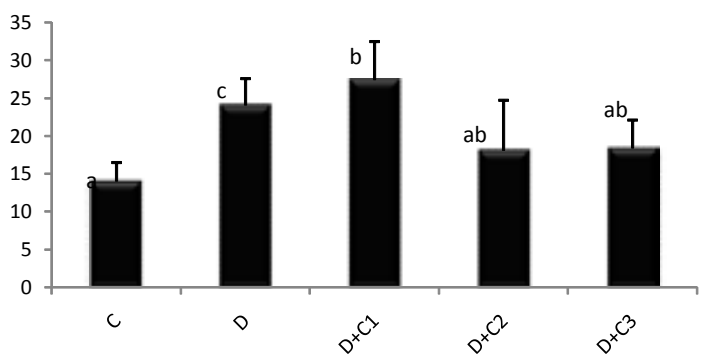

Figure 2: Effect of Karkni extract treatment on ALAT and ASAT activity in diabetic rats. Values with different superscript letters $(a, b, c)$ indicate significant differences among groups at $P<0.05$ by Duncan's multiple range test.

C: Control; D: Rats with Alloxane-induced diabetes; D+C1: Rats treated with $125 \mathrm{mg} / \mathrm{kg} / \mathrm{day} ; \mathrm{D}+\mathrm{C} 2$ : Rats treated with $250 \mathrm{mg} / \mathrm{kg} / \mathrm{day} ; \mathrm{D}+\mathrm{C} 3$ : Rats treated with $375 \mathrm{mg} / \mathrm{kg} /$ day

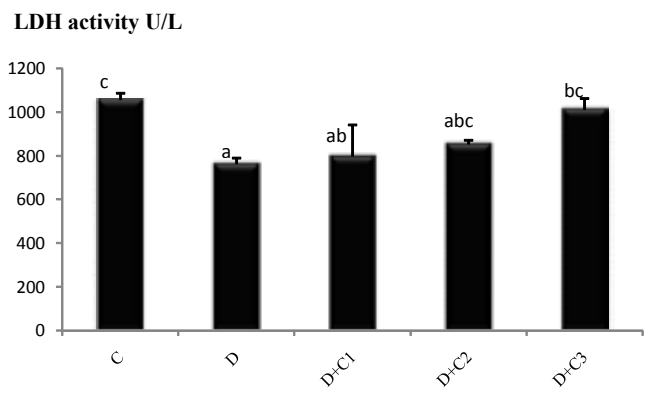

$\gamma$-GT activity $\mathbf{U} / \mathbf{L}$

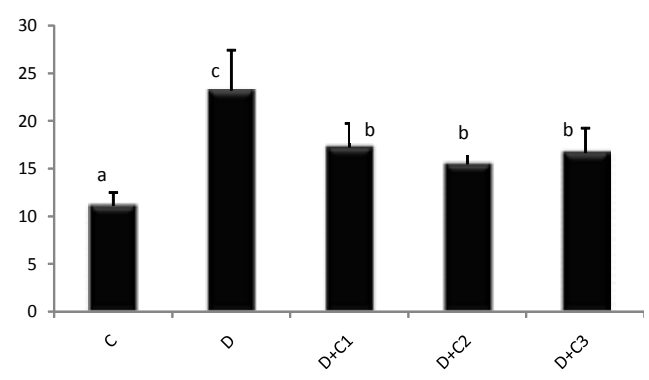

Figure 3: Effect of Karkni extract treatment on LDH and y -GT activity in diabetic rats. Values with different superscript letters $(a, b, c)$ indicate significant differences among groups at $P<0.05$ by Duncan's multiple range test.

C: Control; D: Rats with alloxane-induced diabetes; D+C1: Rats treated with $125 \mathrm{mg} / \mathrm{kg} /$ day; D+C2: Rats treated with $250 \mathrm{mg} / \mathrm{kg} /$ day; D+C3: Rats treated with $375 \mathrm{mg} / \mathrm{kg} /$ day 
Citation: Ghrairi F, Amira EA, Henda C, Lahouar L, Achour L, et al. (2012) Hypoglycemic and Hypolipidemic Effects of Raisin Aqueous Extract "Karkni" in Alloxan-Induced Diabetic Rats. J Diabetes Metab 3: 211. doi:10.4172/2155-6156.1000211

Page 3 of 5

\begin{tabular}{|c|c|c|c|c|c|c|}
\hline & Total Cholesterol TC(mg/dl) & $\begin{array}{l}\text { Triglyceride } \\
\text { TG (mg/dl) }\end{array}$ & $\begin{array}{l}\text { High density } \\
\text { HDL (mg/dl) }\end{array}$ & $\begin{array}{l}\text { Low density } \\
\text { LDL (mg/dl) }\end{array}$ & $\begin{array}{l}\text { LDL/HDL } \\
(\mathrm{mg} / \mathrm{dl})\end{array}$ & $\begin{array}{l}\text { Coronary risk } \mathrm{CT} / \mathrm{HDL} \\
(\mathrm{mg} / \mathrm{dl})\end{array}$ \\
\hline Control group (C) & $56,84 \pm 9,66$ bc & $51,37 \pm 13,32^{\mathrm{a}}$ & $19,59 \pm 5,5^{b}$ & $13,56 \pm 5,46^{a}$ & $0,62 \pm 0,19^{a}$ & $2,87 \pm 0,34^{\mathrm{ab}}$ \\
\hline Diabetic group (D) & $61,77 \pm 4,71^{\mathrm{c}}$ & $63,77 \pm 3,75^{b}$ & $15,66 \pm 6,92^{a}$ & $17,05 \pm 7,61^{\mathrm{a}}$ & $1,06 \pm 0,83^{a}$ & $3,94 \pm 0,60^{c}$ \\
\hline$D+C 1$ & $49,6 \pm 17,49$ ab & $44,28 \pm 8,51^{\mathrm{a}}$ & $15,52 \pm 1,43^{a}$ & $13,40 \pm 6,24^{a}$ & $0,87 \pm 0,64^{a}$ & $3,19 \pm 0,12^{\mathrm{bc}}$ \\
\hline$D+C 2$ & $46,90 \pm 7,51$ a & $40,29 \pm 14,89^{a}$ & $16,24 \pm 2,67^{a}$ & $12,24 \pm 8,23^{a}$ & $0,74 \pm 0,48^{a}$ & $2,82 \pm 0,32^{\mathrm{a}}$ \\
\hline$D+C 3$ & $54,52 \pm 13,45^{\mathrm{abc}}$ & $51,47 \pm 19,88^{a b}$ & $16,62 \pm 6,17^{a}$ & $14,28 \pm 0,26^{a}$ & $0,85 \pm 0,39^{a}$ & $3,28 \pm 1,04^{\mathrm{ab}}$ \\
\hline
\end{tabular}

Values are expressed as means $\pm S E(n=8)$. Values with different superscript letters $(a, b, c)$ indicate significant differences among groups at $P<0.05$ by Duncan's multiple range test

C: Control; D: Rats with Alloxane-induced diabetes; D+C1: Rats treated with 125mg/kg/day; D+C2: Rats treated with 250mg/kg /day; D+C3: Rats treated with 375 mg/kg/ day

Table 1: Effect of "Karkni" extract on lipid profile of alloxan-induced diabetic of rats.

\begin{tabular}{|l|l|l|l|l|l|}
\hline & $\begin{array}{l}\text { Creatinine } \\
(\mu \mathrm{mol} / \mathrm{l})\end{array}$ & $\begin{array}{l}\text { Urea } \\
(\mathrm{mmol} / \mathrm{l})\end{array}$ & $\begin{array}{l}\text { Uric Acid } \\
(\mu \mathrm{mol} / \mathrm{l})\end{array}$ & $\begin{array}{l}\text { Protéine } \\
(\mathrm{g} / \mathrm{l})\end{array}$ & $\begin{array}{l}\text { HbA1c } \\
(\mathrm{g} / \mathrm{l})\end{array}$ \\
\hline Control group (C) & $44 \pm 6.55 \mathrm{ab}$ & $10.53 \pm 1.08 \mathrm{a}$ & $152.5 \pm 61.51 \mathrm{ab}$ & $71.25 \pm 5.30 \mathrm{bc}$ & $155.66 \pm 9.12 \mathrm{~b}$ \\
\hline Diabetic control (D) & $45.5 \pm 6.98 \mathrm{ab}$ & $7.94 \pm 1.72 \mathrm{a}$ & $187.42 \pm 56.34 \mathrm{~b}$ & $79.66 \pm 7.75 \mathrm{c}$ & $141.65 \pm 16.93 \mathrm{ab}$ \\
\hline $\mathrm{D}+\mathrm{C} 1$ & $43 \pm 7.21 \mathrm{ab}$ & $8.60 \pm 2.49 \mathrm{a}$ & $147.57 \pm 23.34 \mathrm{ab}$ & $53.25 \pm 1.06 \mathrm{a}$ & $133.02 \pm 15.48 \mathrm{a}$ \\
\hline $\mathrm{D}+\mathrm{C} 2$ & $47 \pm 1.87 \mathrm{~b}$ & $8.41 \pm 2.26 \mathrm{a}$ & $136.8 \pm 21.01 \mathrm{a}$ & $62.66 \pm 7.76 \mathrm{ab}$ & $147.61 \pm 17.4 \mathrm{ab}$ \\
\hline $\mathrm{D}+\mathrm{C} 3$ & $38 \pm 12.91 \mathrm{a}$ & $9.46 \pm 4.98 \mathrm{a}$ & $183.2 \pm 44.65 \mathrm{~b}$ & $63.88 \pm 20.62 \mathrm{ab}$ & $6.41 \pm 0.56 \mathrm{~b}$ \\
\hline
\end{tabular}

Values are expressed as means \pm SE $(n=8)$.Values with different superscript letters $(a, b, c)$ indicate significant differences among groups at $P<0.05$ by Duncan's multiple range test

C: Control; D: Rats with Alloxane-induced diabetes; D+C1: Rats treated with $125 \mathrm{mg} / \mathrm{kg} / \mathrm{day}$; D+C2: Rats treated with $250 \mathrm{mg} / \mathrm{kg} / \mathrm{day}$; D+C3: Rats treated with $375 \mathrm{mg} / \mathrm{kg} /$ day

Table 2: Effect of "Karkni" extract on creatinine, Urea, Uric acid, Total protein and Hemoglobin levels of alloxan-diabetic rats.

$\mathrm{D}+\mathrm{C} 1, \mathrm{D}+\mathrm{C} 2$ and $\mathrm{D}+\mathrm{C} 3$. Of the 3 doses of raisin tested, the $250 \mathrm{mg} / \mathrm{kg}$ dose was found to be the most effective in reducing blood glucose levels during the 4 weeks.

\section{Effects of "Karkni" extract on plasma lipid profile like TC, TG, LDL and HDL}

In our study, induction of diabetes significantly altered the normal lipid profile levels compared to control rat (Table 1). Administration of three doses of "Karkni" extract significantly decreased $(\mathrm{P}<0.05)$ plasma TC, TG and LDL cholesterol levels compared to diabetic group. Moreover, the LDL cholesterol in the $(\mathrm{D}+\mathrm{C} 2)$ group was lower than that in the other groups $(D+C 1)$ and $(D+C 3)$. HDL cholesterol concentrations were increased in the $(D+C 2)$ and $(D+C 3)$ groups than in diabetic group. Consequently, the ratio of LDL/HDL ratio was decreased significantly in $(\mathrm{D}+\mathrm{C} 2)$ group than in the diabetic, $(\mathrm{D}+\mathrm{C} 1)$ and $(\mathrm{D}+\mathrm{C} 3)$ groups $(\mathrm{p}<0.05)$, whereas, the coronary risk was significantly lower in the $(D+C 2)$ and $(D+C 3)$ groups than in the others groups.

\section{Effects of "Karkni" extract on creatinine, Urea, Uric acid, Total protein, Hemoglobin and HbAlc levels}

Plasma levels of blood uric acid were increased following diabetes induction (Table 2). There were significant difference between the diabetic and the control group, $187.42 \pm 56.34$ and $152.5 \pm 61.51$ $\mu \mathrm{mol} / \mathrm{l}$ respectively. But the lowest levels were observed in $(\mathrm{D}+\mathrm{C} 2)$ group, $(136.8 \pm 21.01 \mu \mathrm{mol} / \mathrm{l})$. Also the level of creatinine was increased in the diabetic group but the difference was not significant. Moreover, plasma protein levels were significantly increased in the diabetic rats $(p<0.05)$. But after 4 weeks of treatment with "Karkni" extract, the levels of protein were decreased in $(D+C 1),(D+C 2)$ and $(D+C 3)$ groups. Increased $\mathrm{HbA1c}$ levels were noticed in diabetic rats compared to control rats whereas hemoglobin and urea levels were significantly lowered in diabetic rats. But they were restored after four weeks of treatment by "Karkni" extract.

\section{Effects of “Karkni” extract on enzymes activity}

Induction of diabetes led to increased ALAT activity (Figure 2). After four weeks of treatment, activity of this enzyme was decreased in $(D+C 1)$ and $(D+C 2)$ groups but it still remained higher in the $(\mathrm{D}+\mathrm{C} 3)$ group. Concerning ASAT activity, it was also found that alloxan-induced diabetes increased, but it was significantly decreased in $(\mathrm{D}+\mathrm{C} 2)$ and $(\mathrm{D}+\mathrm{C} 3)$ group (Figure 3$)$. Also a significant $(\mathrm{P}<0.001)$ reduction of LDH activity was observed in diabetic group compared to control rats. By contrast, $\gamma$-GT activity was increased significantly in diabetic rats $(\mathrm{p}<0.05)$. After 4 weeks, enzyme activity was restored in $(\mathrm{D}+\mathrm{C} 1),(\mathrm{D}+\mathrm{C} 2)$ and $(\mathrm{D}+\mathrm{C} 3)$ groups.

\section{Discussion}

Raisin polyphénols have demonstrated significant antioxidant anticarcinogenic, anti-inflammatory, thermogenic, probiotic, and antimicrobial properties in numerous human, animal, and in vitro studies [6]. But the effect of raisin polyphenols in diabetes is still unknown. The present study was conducted to determine the effect of feeding 3 doses of raisin extract "Karkni" on the lipid parameters in alloxan rats. Alloxan, at a dose of $120 \mathrm{mg} / \mathrm{kg}$ body weight, caused sufficient damage to pancreatic $\beta$ cells so that secreted insulin was not enough to regulate blood glucose and resulted in a significant increase in blood glucose levels [24-26]. In our experiment, we had shown that raisin extract decreased plasma glucose for 4 weeks compared with those of the diabetic's controls. Both doses $(125$ and $250 \mathrm{mg} / \mathrm{kg})$ of the extract showed a significant hypoglycemic effect but rats treated with $375 \mathrm{mg} / \mathrm{kg}$ of "Karkni" extract showed significant increases in blood glucose after three weeks. These results can be related with the carbohydrates content in raisin. Previous studies had shown that hypoglycemic effect of many herbs was related to flavonoids content and these constituents can preserve the insulin-secreting capacity and viability of pancreatic $\beta$ cells [27]. Therefore, the presence of these constituents in our variety of raisin may explain the hypoglycemic activity, and we can conclude that the antioxidative activities of raisin 
extract in alloxan-induced diabetes, at least in part, may be related to antihyperglycemic capability. The present study found that the intake of "Karkni" extract significantly lower plasma total cholesterol, triglycerides and LDL cholesterol concentrations but increased serum HDL cholesterol in $(\mathrm{D}+\mathrm{C} 1),(\mathrm{D}+\mathrm{C} 2)$ and $(\mathrm{D}+\mathrm{C} 3)$ groups when compared with those of diabetic control. Also decreased level of coronary risk was observed in the same group but it was especially interesting in $(\mathrm{D}+\mathrm{C} 2)$ group, $(2.82 \mathrm{mg} / \mathrm{dl})$. These results were similar to those found by Bruce et al. [11] and Gardner et al. [12]. High levels of circulating cardiac dysfunction/damage markers such as, LDH and uric acid, represent a sensitive predictor of increased cardiac complications [28]. In our study, "Karkni" extract showed a significant decrease in levels of uric acid in $(D+C 1)$ and $(D+C 2)$ groups when compared with those of diabetic control. But it was still remaining higher in $(\mathrm{D}+\mathrm{C} 3)$ group. In diabetic rats the elevation observed in uric acid level could be due to the increased abundance and activity of xanthine oxidase. It was responsible for the formation of uric acid and also serves as an important biological source of ROS (superoxide) that contribute to oxidative damage involved in many pathological processes such as diabetes, atherosclerosis, cancer and aging [29-31]. Moreover, decreasing levels of HbA1c observed in $(\mathrm{D}+\mathrm{C} 2)$ group can reduce the risk of lipid peroxidation [32]. These explain the important role of raisin to decrease cardiac damage markers in diabetic person with $250 \mathrm{mg} / \mathrm{kg}$.

Also results presented in table 2 clearly revealed that the administration of the three concentrations of "Karkni" extract to the diabetic rats could restore the changes in the levels of hemoglobin, urea, creatinine and total protein after 4 weeks of treatment to their normal levels. Lal et al. proved that in diabetes, elevated levels of serum urea, uric acid and creatinine are observed which may be due to renal damage caused by abnormal glucose regulation or elevated glucose and glycosylated protein tissue levels [33]. So it could be concluded that the above action of raisin may be due to its potential to control hyperglycemia and renal damage in diabetic rats. Alloxan induces increase of AST, and ALT activity in rats (Figure 2). This results were similar than that observed with streptozotocin induced diabetic rats [34]. Restoration of the normal level of ALAT may indicate the normalizing effect of both 125 and $250 \mathrm{mg} / \mathrm{kg}$ of "Karkni" extract. As for ASAT activity, restoration of the normal level was observed only with 250 and $375 \mathrm{mg} / \mathrm{kg}$ of "Karkni" extract. A change in enzyme activity is presumed to be due to the decreased blood insulin concentration [35], but is also related to energy metabolism, as these enzymes play a role in gluconeogenesis [36]. As for LDH activity, results from our experiment show that diabetes decreases LDH activity (Figure 3). These result are similar than Tormo et al. [37], but not than Melinkeri et al. [38]. A highly significant elevation in the activity of $\gamma$-GT was observed in plasma of alloxan-induced diabetic rats. But after treatment of raisin, increased activity of this enzyme was lowered to near normal that indicates the possible prevention of necrosis in the liver by "Karkni" extract. The same result was observed by McLennan et al. [39]. Also, the increment of the activities of AST, ALT and LDH in plasma is mainly due to the leakage of these enzymes from the liver cytosol into the blood stream [40], which gives an indication on the hepatotoxic effect of alloxan, but raisin extract reduced the activity of these enzymes in plasma so the oral administration of "Karkni" extract had a beneficial effect on the diabetic state reducing the hyperglycemia as well as hyperlipidemia.

\section{Conclusion}

In conclusion, our study demonstrates that "Karkni" extract corrects hyperglycemia and dyslipidemia, thus improving the atherogenic index.
The $250 \mathrm{mg} / \mathrm{kg}$ dose was found to be the most effective in restoring changes during the 4 weeks. This implies that raisin can prevent or be helpful in reducing the complications of diabetes. However, further investigations to fully identify the biologically active ingredients and to define the precise molecular mechanism(s) of these effects are required.

\section{References}

1. Ogbonnia SO, Odimegwu JI, Enwuru VN (2008) Evaluation of hypoglycemic and hypolipidaemic effects of ethanolic extracts of Treculia africana Decne and Bryophyllum pinnatum Lam. and their mixture on streptozotocin (STZ)-induced diabetic rats. Afr J Biotechnol 7: 2535-2539.

2. Edem DO (2009) Hypoglycemic Effects of Ethanolic Extracts of Alligator Pear Seed (Persea Americana Mill) in Rats. European Journal of Scientific Research 33: $669-678$.

3. Ceriello A (2000) Oxidative stress and glycemic regulation. Metabolism 49: $27-$ 29.

4. Yim S, Malhotra A, Veves A (2007) Antioxidants and CVD in diabetes: where do we stand now. Curr Diab Rep 7: 8-13.

5. Pushparaj PN, Low HK, Manikandan J, Tan BK, Tan CH (2007) Anti-diabetic effects of Cichorium intybus in streptozotocin-induced diabetic rats. J Ethnopharmacol 111: 430-434.

6. Williamson G, Carughi A (2010) Polyphenol content and health benefits of raisins. Nutr Res 30: 511-519.

7. Witherspoon B (2000) Raisins to the rescue! Sch Food service Nutr 54: 60-63

8. Meng J, Fang Y, Zhang A, Chen S, Xu T, et al. (2011) Phenolic content and antioxidant capacity of Chinese raisins produced in 407 Xinjiang Province. Food Res 44: 2830-2836.

9. Spiller GA, Schultz L, Spiller M, Ou B (2002) Sun-dried raisins help prevent oxidative DNA damage during intense athletic activity. J Am Coll Nutr 21: 487

10. Keen CL, Schram DD (Unpublished data) The effect of raisins on antioxidant capacity and cholesterol concentration in human subjects.

11. Bruce B, Spiller GA, Klevay LM, Gallagher SK (2000) A diet high in whole and unrefined foods favorably alters lipids, antioxidant defenses, and colon function. J Am coll Nutr 19: 61-67.

12. Gardner CD, Coulston A, Chatterjee L, Rigby A, Spiller G, et al. (2005) The effect of a plant-based diet on plasma lipids in hypercholesterolemic adults. Ann Intern Med 142: 725-733.

13. Wijewickreme AN, Kitts DD (1998) Metal chelating and antioxidant activity of model Maillard reaction products. Adv Exp Med Biol 434: 245-254.

14. Mastrocola D, Munari M, Cioroi M, Lerici CR (2000) Interaction between Maillard reaction products and lipid oxidation in starch-based model systems. $J$ Sci Food Agr 80: 684-690.

15. Gogus F, Bozkurt H, Eren S (1998) Kinetics of Maillard reactions between the major sugars and amino acids of boiled grape juice. LebensmittelWissenschaftund-Tech 31: 196-200.

16. Pradeep Kumar R, Sujathan D, Mohamed Saleem TS, Madhusudhana Chetty C, Ranganayakulu D (2010) Potential antidiabetic and antioxidant activities of Morus indica and Asystasia gangetica in alloxan-induced diabetes mellitus. J Exp Pharmacol 2: 29-36.

17. Dunn JS, Sheehan HL, Mcletchie NGB (1943) Necrosis of islets of langerhans produced experimentally. Lancet 241: 484-487.

18. Goldener MG, Gomori G (1964) Studies on the mechanism of alloxan diabetes. Endocrinol 35:241-248.

19. Friedewald WT, Levy RI, Fredrickson DS (1972) Estimation of the concentration of low-density lipoprotein cholesterol in plasma, without use of the preparative ultracentrifuge. Clin Chem 18: 499-502.

20. Drabkin DL, Austin JH (1932) Spectrophotometric studies: I. Spectrophotometric constants for common hemoglobin derivatives in human, dog and rabbit blood. J Biol Chem 98: 719-733.

21. Bergmeyer HU (1975) New values for the molar extinction coefficients of NADH and NADPH for the use in routine laboratories (author's transl). Z Clin Chem Klin Biochem 13: 507-508. 
Citation: Ghrairi F, Amira EA, Henda C, Lahouar L, Achour L, et al. (2012) Hypoglycemic and Hypolipidemic Effects of Raisin Aqueous Extract "Karkni" in Alloxan-Induced Diabetic Rats. J Diabetes Metab 3: 211. doi:10.4172/2155-6156.1000211

Page 5 of 5

22. Lum G, Gambino SR (1972) Serum gamma-glutamyl transpeptidase activity as an indicator of disease of liver, pancreas, or bone. Clin Chem 18: 358-362.

23. Bergmeyer HU, Bowers GN Jr, Horder M, Moss DW (1976) Provisional Recommendations on IFCC Methods for the Measurement of Catalytic Concentrations of Enzymes. Part 2. IFCC method for aspartate aminotransferase. Clin Chim Acta 70: F19-F29.

24. Wexler BC (1976) Effects of hypophysectomy on alloxan-diabetic, arteriosclerotic, breeder vs. non-arteriosclerotic, virgin rats. Atherosclerosis 25 : 13-30.

25. Mansour HA, Newairy AS, Yousef MI, Sheweita SA (2002) Biochemical study on the effects of some Egyptian herbs in alloxan-induced diabetic rats. Toxicology 170: 221-228.

26. Das J, Vasan V, Sil PC (2012) Taurine exerts hypoglycemic effect in alloxaninduced diabetic rats, improves insulin-mediated glucose transport signaling pathway in heart and ameliorates cardiac oxidative stress and apoptosis. Toxicol Appl Pharmacol 258: 296-308

27. Yugarani T, Tan BK, Teh M, Das NP (1992) Effects of polyphenolic natural products on the lipid profiles of rats fed high fat diets. Lipids 27: 181-186.

28. Howard-Alpe GM, Sear JW, Foex P (2006) Methods of detecting atherosclerosis in non-cardiac surgical patients; the role of biochemical markers. $\mathrm{Br} \mathrm{J}$ Anaesth 97: 758-769.

29. Cos P, Ying L, Calomme M, Hu JP, Cimanga K, et al. (1998) Structure-activity relationship and classification of flavonoids as inhibitors of xanthine oxidase and superoxide scavengers. J Nat Prod 61: 71-76.

30. Akhileshwar V, Patel SP, Katyare SS (2007) Diabetic cardiomyopathy and reactive oxygen species (ROS) related parameters in male and female rats: a comparative study: A comparative study. Indian J Clin Biochem 22: 84-90.
31. Thomson MJ, Puntmann V, Kaski JC (2007) Atherosclerosis and oxidant stress: the end of the road for antioxidant vitamin treatment? Cardiovasc Drugs Ther 21: 195-210.

32. Varashree BS, Bhat GP (2011) Correlation of Lipid Peroxidation with Glycated Haemoglobin Levels in Diabetes Mellitus. J Health Allied Sci 10: 11.

33. Lal SS, Sukla Y, Singh A, Andriyas EA, Lall AM (2009) Hyperuricemia, high serum urea and hypoproteinemia are the risk factor for diabetes. Asian $\mathrm{J}$ Med Sci 1: 33-34.

34. Hahm SW, Park J, Son YS (2011) Opuntia humifusa stems lower blood glucose and cholesterol levels in streptozotocin-induced diabetic rats. Nutr Res 31: 479487

35. Genet S, Kale RK, Baquer NZ (2002) Alterations in antioxidant enzymes and oxidative damage in experimental diabetic rat tissues: effect of vanadate and fenugreek (Trigonellafoenum graecum). Mol Cell Biochem 236: 7-12.

36. Devlin TM (1998) Textbook of Biochemistry with Clinical Correlations. Edgard Blucher Ltda, Sao Paulo.

37. Tormo MA, Martinez IM, Romero de Tejada A, Gil-Exojo I, Campillo JE (2002) Morphological and enzymatic changes of the small intestine in an n0-STZ diabetes rat model. Exp Clin Endocrinol Diabetes 110: 119-123.

38. Melinkeri RR, Sontakke AN, Kulkarni AM (1990) Serum zinc and zinc containing enzymes in diabetes mellitus. Indian J Med Sci 44: 173-177.

39. McLennan SV, Heffernan S, Wright L, Rae C, Fisher E, et al. (1991) Changes in hepatic glutathione metabolism in diabetes. Diabetes 40: 344-348.

40. Concepcion Navarro M, Pilar Montilla M, Martin A, Jimenez J, Pilar Utrilla M (1993) Free radical scavenger and antihepatotoxic activity of Rosmarinus tomentosus. Planta Med 59: 312-314. 